\title{
The Land of Storms and the region where the country's heart beats: changing images of peripherality in Hungary
}

\author{
Péter BALOGH ${ }^{1}$
}

\begin{abstract}
Processes of peripheralisation have over the past years been studied from structuralist and discursive angles alike. There is at the same time a growing awareness that the two need to be studied together. This paper makes an attempt by showing how socio-material and discursive processes can co-constitute centre-periphery relations, on the example of Hungarian regions. Particular focus is given to Békés County as well as to Central Hungary. The empirical sources consist of sociographic books and popular scientific articles written mostly by geographers. The former show that images of peripheral areas have significantly altered over time. While the "Land of Storms" - an epithet associated with Békés County - for instance has typically stood for toughness and combat-readiness up until the 1950s, it has been connected more with passivity and tardiness since the 1980s. Despite the changing nature of these images they have curiously always been attributed to the region's peripherality, even though a rising spirit for instance has not been a typical feature of peripheries in Hungary. The analysis of popular scientific articles reveals that they are usually written from the centre's perspective, targeting the centre's audience. Further, certain places are peripheralised by being depicted as forgotten or remote; the natural endowments of rural and sparsely populated areas are not rarely exotified and romanticised. Such descriptions may make so-called peripheries more interesting for readers (in the centres), yet they also maintain old images of such areas that can considerably affect their development potentials.
\end{abstract}

Keywords: peripherality, images, discourses, literature, film, popular science, regional development, Békés County

\section{Introduction}

Over the past years the intensifying processes of peripheralisation have been studied from political economic (SмIтH, A. and Timár, J. 2010; NAgY, G. et al. 2012), structural-territorial (PÉNZES, J. 2013), hinterland development ( $c f$. Timár, J. and Kovács, Z. 2009), and discursive angles (see below). There is at the same time an emerging body of literature that tries to connect the material with the discursive (BeEtz, S. 2008; LANG, T. 2012). This paper makes such an attempt by showing how socio-material and discursive processes can co-constitute centre-periphery relations in the case of Hungarian regions and places.
While considering a number of examples, particular attention is paid to Békés County, often regarded as one of the most peripheral parts of the country. This and other regions' relations and positions are considered not least vis-á-vis the (administrative) region of Central Hungary and especially the capital city Budapest. The particular questions that the paper will address are: What kind of notions and images are typically produced for so-called peripheral areas, and why? How can these affect public notions of such places and thereby their development chances?

The paper is also making an attempt at empirical novelty. Earlier studies on peripherality discourses and labels have focused on media images (Avraham, E. and First,

\footnotetext{
${ }^{1}$ Research Group, Alföld Department, Institute for Regional Studies, Centre for Economic and Regional Studies, HAS. H-5600 Békéscsaba, Szabó Dezső u. 42. E-mail: baloghp@rkk.hu
} 
A. 2006; EriKsson, M. 2008), spatial development plans (e.g. LANG, T. 2012), or semantic elements (Meyer, F. and Miggelbrink, J. 2013). To the best of my knowledge, few or no scholars of peripherality have specifically targeted (classic) literature, popular science, and movies as primary sources. Yet, given their widespread and popular character such materials might prove to be a key in finding the roots of shapers of public notions of places here dealt with. Hence, in this investigation I made use of the following two main groups of empirical material.

On the one hand, non-fiction books as well as films were chosen that deal with rural and peripheral areas in Hungary and especially in Békés County. Here I used 8-9 recent and older sources that remain relevant. The second group of empirical sources consists mainly of articles in popular but still demanding publications, especially in A Földgömb, the popular scientific journal of the Hungarian Geographical Society. While some of the information may be exaggerated for marketing purposes, important data can be found on this magazine on the publisher's website (Heiling Média Kft, 2015).

We learn that $A$ Földgömb is one of the most popular scientific magazines in Hungary, reporting on "spectacular regions, their inhabitants, and little-known environments...". It is issued in 21,700 copies ten times annually, and has over 6,000 subscribers and around 70,000 readers. The readership shall consist of both men and women aged between 18-55 years, typically decision- as well as opinion-makers, with secondary or tertiary education (with over $40 \%$ of subscribers holding a doctoral title). Also important, „it is a unique feature of the readership to read almost every article; with subscribers collecting the 100-page magazine, meaning they return to older copies and re-read the articles" (ibid).

Further, a free online version of $A$ Földgömb also exists, suggesting it is even more widely read and available to a broader readership. Nevertheless, it can be assumed that very old copies of popular scientific magazines are rarely read, so my selected time range is much shorter here (than with classic literary texts) - all articles are from the 2000s. I chose 13-14 contributions in this category, most of which dealing with various Hungarian regions.

The sources above are critically analysed, focusing in particular on the ways they portray so-called peripheral and rural areas. I did not adopt a definition of peripherality on my own but relied instead on the sources that themselves use the term periphery as well as closely related concepts such as marginality, and then went on analysing how different writers have been using these notions. Before moving on to the empirical data, some important earlier work in the field of peripherality studies are presented.

\section{Peripherality: some conceptual ideas and earlier studies}

As a result of the Westphalian order, peripherality was long seen as a concomitant feature of territoriality and was, thus, rarely problematised. This changed in the 1970s, when peripherality was increasingly studied as a phenomenon and a crucial and unavoidable feature of capitalism (WALLERSTEIN, I. 1974; Petras, J.F. 1976). While still a marxist, Lefebvre, H. (1974) became a forerunner in changing this by claiming that the periphery's one-sided dependence on the centre is an expression of the socialisation of space ( $c f$. SHIELDS, R. 1991). With the cultural and spatial turn (WARF, B. and ARIAS, S. 2009) since the 1980s, peripherality is increasingly seen as a relational process - captured with the concept of peripheralisation - that is constantly under (re)construction and (re)negotiation. PAAsI, A. (1995) showed on the example of different geographic scales in Finland how peripherality is socially constructed rather than given.

At the same time, a relational thinking implies that "peripheries mean different things in different places and for different people" (ibid, p. 254-255). In her study on a small Portuguese bordertown, DE Oliveira, S.M. (2002, p. 254) noted that while outsiders may perceive the 
local inhabitants as being at the periphery, they themselves do not. Closely related, the relativity of space means that any place on Earth cannot be peripheral on its own but only in relation to another place; for instance a small town vis-á-vis the capital, a tiny impoverished state vis-á-vis a large and powerful one, and so on. Hence, there are different ways of understanding spaces, places and landscapes, which, thus, become ambiguous and paradoxical rather than straight-forward and homogenous (Forsberg, G. 1996). Additionally, discourses of spaces can significantly alter in time (GYuris, F. 2014).

The cultural turn emphasises that cultural meanings of space are significant, and not just for identity but also for "the construction of the economic meanings of peripheral areas" (PaAsi, A. 1995, p. 255). For Shields, R. (1991, p. 5), marginal places "carry the image and stigma of their marginality, which becomes indistinguishable from any empirical identity they might have had". In a study on British local authority estates, Hastings, A. and DeAn, J. (2003) noted how the term 'nogo' estate became a convenient way for the media and public alike to label a wide variety of social environments, despite the fact that only a small number of these experienced unrests. Such labelling then exacerbated neighbourhood decline whereby those who could move out, leaving behind the more vulnerable: „labelled as failures, people accept and internalize this negative image. Outsiders - professionals, politicians, the media - reflect, reinforce and magnify that image. People expect to be treated badly and their image of themselves and the estate takes a further battering" (TAYLOR, M. 1998, p. 821).

Similarly, according to LANG, T. (2012, p. 1751) "(collective) self-images of actors in peripheralized regions are highly relevant and often lead to mental lock-ins setting off downward spirals of decline". A number of examples from eastern Germany have been recognised: the town of Guben shall have "collectively resigned" (BüRKNER, H. 2002); the German-Polish borderland be "peripherised in the heads" (Matthiesen, U. 2002, p. 3), and Johanngeorgenstadt be a "self-label of a dying or already dead city" (SteInfüHRER, A. and Kabisch, S. 2007, p. 120). As LANG, T. (2012, p. 1751) notes, as a consequence of such categories - and arguably their internalisation - "emigration appears as escape or at least as discursively constituted modus agendi. If such cognitive developments become dominant, complete regions tend to be paralysed and appear hostile to innovation". In sum, spatial discourses are not only shaped by locational factors but also by images. Being classified as centre or periphery does not only affect actual developments but also potential development chances. Spatial inequality is, thus, not just a result of economic and political processes; rather, the difference between centre and periphery mirrors the societal construction of spatial order (BeEtz, S. 2008, p. 13, author's translation).

Finally, yet another body of literature has emphasised the (potentially) positive elements of a marginal position, not just in its function of creating something new and innovative but also in bringing together various already established centres. Chinese diaspora literature in the United States (LEE, L.O. 1991), or the Kaliningrad region's potential bridging role between the rest of Russia and the EU (Browning, C.S. and Joenniemi, P. 2004) are just two examples of a hybrid zone, meeting point, or a semiosphere (Lotman, Y.M. 2005) or third space (SoJA, E. 1996). It is with such a conceptual baggage that we now turn to our empirical case(s).

\section{Processes of socio-economic polarisation in Békés County}

Hungary and Békés County offer illustrative examples of "social spatialisation" (SHIELDS, R. 1991). The country's postal codes, roadnetwork, and dialling codes all reflect the spatial hierarchy: the capital Budapest carries the number one, its surroundings the number two, with the remaining Hungarian regions being allocated subsequent numbers, clockwise on the map. 
From a modernist and structuralist perspective, a powerful narrative can be presented that portrays Békés County as a peripheral area. The region is located in the south-eastern corner of Hungary - itself not an economically vibrant country - bordering Romania, one of the poorest member states of the European Union (EU). As PaAsI, A. (1995, p. 255) noted, "since the territorial system is always changing, the analysis of peripheries cannot ignore the historical context". The region's history-in-a-nutshell could then be written as something like the following. The Great Hungarian Plain including Békés County has always tended to be a backward and peripheral region. Due to its physical features - lowlands - that make it easily accessible, the area has often been invaded by different peoples (Tartars, Turks etc.), whose empires' borders it often constituted. Up until the Treaty of Trianon in 1920, Békés County's position was in fact in the centre of the Kingdom of Hungary, but it has been a border region ever since. Its administrative centre was moved from historical Gyula (now at the Romanian border) to Békéscsaba, which was mostly developed during the years of state socialism. For a brief period - between May 2004 and December 2006 - Békés County was even at the external border of the EU and it still is of the Schengen Area. Hence, from a conventional or absolute understanding of space the study area is in many ways a peripheral one.

In socio-economic terms the story is a very similar one. Békés County can be described as an area characterised by high rates of poverty, unemployment, out-migration, and an aging population (Ló́csEI, H. et al. 2013). The inhabitants of the county have the third lowest average income (KIss, A. 2014) and purchasing power (Orosz, M. 2014) among Hungary's twenty meso-level units. At the same time, the share of state-subsidised public labour - a strongly debated measure to combat unemployment (BАKó, T. et al. 2014) - of the region's total labour force is among the highest. Békés's road-network is among the poorest of all Hungarian counties, with no motorway so far running through its territory. Due to its peripheral location, poor transport infrastructure, and possibly its monotonous landscape, the region's touristic potential remains limited. Such a negative description unfortunately coincides with socio-economic realities to a large extent, but it is not the whole picture.

A somewhat different picture emerges if we take into account the following factors that are also characteristics of Békés County. Its many rivers make it a popular tourist destination for various water sports and recreation (Szabó, V. and Siмкó, G. 2002). While spatowns can be found all over Hungary, Gyula and Orosháza belong to the more famous ones. Békés County's soil is among the most fertile in the EU, even if the area's agricultural industry has seen better days. The region's share of Hungarikum food products - a prestigious label of premium-quality products from Hungary - is clearly over-proportional (ibid, p. 46). Over the past 16-17 years, Gyula and Békéscsaba have each been hosting an annual festival dedicated to two of these "Hungarikums" (pálinka and sausage, respectively), with the events enjoying increased national and international recognition as well as turning attention to the region's agricultural potentials (VJM.HU 2014).

Relatedly, some initiatives have recently been taken to revive the traditional meat industry of the region. At the same time, the railway link linking the county with Budapest is frequently operated and currently under reconstruction to allow for faster travel. Moreover, cross-border traffic from neighbouring Arad County in Romania is significant for the region's commercial and tourism industries, evidenced by the presence of Romanian cars, signs, and people in Békéscsaba. Relatedly, Arad County's large ethnic Hungarian population (approx. 9\%) as well as Békés County's Romanian minority (approx. 1.1\%) has been offering opportunities for various types of exchange across the border.

Thus, while processes of peripheralisation are clearly present in the study area, as LANG, T. (2012, p. 1751) pointed out such processes 
are revisable, as testified by a number of examples even outside the large cities and capitals of Central and Eastern Europe. Historic and spa towns - e.g. Świnoujście in Poland (Lundén, T. et al. 2009), Karlovy Vary in the Czech Republic, Visegrád and Gyula in Hungary - and formerly heavy industry-dominated places that managed to reorient towards modern industries - such as Hoyerswerda in Germany (LANG, T. 2012, p. 1751), or the Hungarian counties of Komárom-Esztergom, Győr-Moson-Sopron and Fejér - are doing comparatively well. Yet the point of this article is not to find out whether Békés County is a peripheral region or not, but to investigate how certain images associated with it can affect its development chances. Hence, it is to the discursive elements that we now turn.

\section{Discursive peripheralisation in Békés County and elsewhere}

Notions of peripherality in literature and film

Images and notions of peripherality are (re)produced in popular culture, and these appear to be changing in time. In the nineteenth century, "the countryside" was rather over-idealised in Hungary (Kovách, I. 2012, p. 32) as in much of Europe, by for instance national romanticist authors and poets such as Sándor Petőfi or János Arany. Spaces until then conceived as rural and peripheral stepped into the foreground by becoming subjects of overromanticisation: in a time of growing urbanisation, longing for the rural did not just represent a search for national authenticity (ibid) but also a desire to return to the "untouched" nature. Under such conditions issues like poverty - also widely connected with rurality (LeIBERT, T. 2013) - were barely dealt with, if at all. The 1930s however saw the rise of the movement of "folk authors" (népi irók), many of whom had come from impoverished rural environments themselves. The term "folk" (népi) was a self-label of this loosely connected group, standing in opposition to the "urban" and "genteel" elites (PÉTER, L. ed. 1994: 1484). Seen as a radical movement by many, the movement's goal was not just to portray social problems - as they observed them along their journeys across the country and beyond - but also to lift these into public consciousness and to promote solutions (ibid).

One of these sociographic monographs, Viharsarok (written by FÉJA, G. 1937; Photo 1) - a name translated into "Land of Storms" in the title of a movie by the same name (Császi, Á. 2014) - deals with roughly the same area that today constitutes Békés County. This was not a coincidental choice, as FÉJA explains (FÉJA, G. 1937/1980, p. 11):

"When the editor presented the plan of this book series and asked me which landscape I would cover I immediately pointed to the southern Tisza Region, Transtisza's and Hungary's "land of storms", where minds and hearts could never reconcile to the existing, to the Hungary that came true.

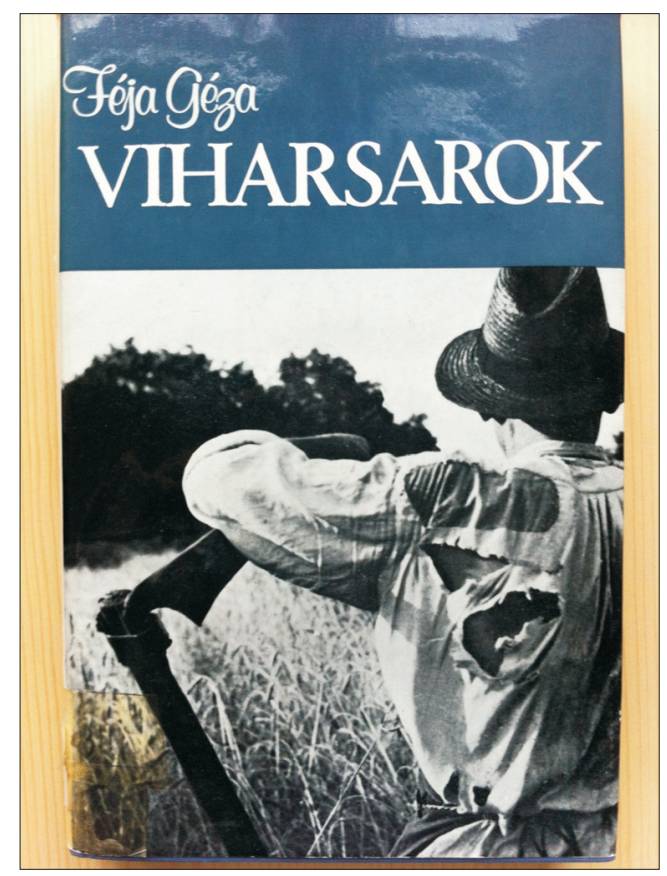

Photo 1. In the 1930s, the Land of Storms was typically portrayed as an inflammable, politically volatile region characterised by peasant uprisings ( $c f$. FÉJA, G. 1937/1980) 
These people were always ready to rise, to start a new life... When a sparkle flew there, Transtisza immediately burst into flames, burning beautifully, as if it was conscious of a better and more human life, rapidly putting up troops against the aristocracy and later against feudal-capitalist powers."

In the same year another similar sociographic work was published, Puszták népe (written by Illyés, GY. 1937). Although dealing with another geographic area (Tolna County), the observations made are very comparable to FÉJA's: the local population is described as heavily polarised in all sorts of ways; socially, economically, culturally etc. Defencelessness and impoverishment best describe the fate of the servantry, whose lives were strongly dependent on and regulated by their feudalistic overlords - including the right to hold guns (ILlYÉs, Gy. 1937/1969, p. 25 ) or even dogs (ibid, p. 7). And yet, "the land of Sió-Sárvíz has always shined intensely and ready-to-stick, like the sword pulled out from the scabbard, as many times as the wind of freedom was blowing... whenever blood could be shed freely, whenever the opportunity arose to pour out stifled bitterness and revenge... The people of the puszta [i.e. Hungarian grassland] are excellent soldiers... not regretting their skin. In heroism and contempt of death only the Bosnians can compete among the monarchy's peoples" (ILlYÉs, Gy. 1937/1969, p. 25).

According to the author, the combat-readiness of the puszta's servants is evidenced by their heroic actions for instance during the revolution of 1848 and World War One (ibid, p. 24-25). The two books have come out in a number of subsequent editions and remain included in the national curriculum for grammar-schools. However, this was not always the case. During the interwar national-conservative regime, FÉJA for instance was sued for "dishonouring the nation" and dismissed from his position as a teacher. His book remained banned during the communist period up until 1957 (Grósz, M. ed. 1995, p. 28) since it suggested allocating small lands to the peasants as a measure to combat their poverty.
Some years later another sociographic book was published that deals with the problems of a rural small town in Békés County. Its title translates into "On the country's edge" (VARGA, D. 1982), which refers to both the area's marginalised inhabitants as well as its physical location. Apart from directing attention to the severe conditions the community at stake has been living with, the author also points out the following:

"The appearance of the problems of peripheries in public opinion has an even stronger effect on social consciousness than the reality would suggest. Social consciousness is namely prone to magnify the negative phenomena of the periphery. This ... leads to exasperation and listlessness not just in the periphery, but also elsewhere. The solution is therefore not to keep silent, on the contrary..." (ibid, p. 11).

Hence, VARGA, D. (1982) is pointing to a potential gap between socio-material realities and perceptions of it. Importantly, he does not make the above point to belittle the problems of peripheralised areas; as the folk writers he too shows a clear commitment to finding solutions (ibid, p. 11-12). But the quote above emphasises the crucial point that images and discourses of peripherality can be very powerful and influential on the whole of society. Nevertheless, the author himself makes some doubtful and essentialising claims, such as that "on the periphery everything unfolds in a different way than in the centres; everything substantial and important takes shape differently than it should" (VARGA, D. 1982, p. 9), or that the village he observed suffers from higher internal income inequalities than other Hungarian settlements (ibid).

The author further suggests that "unknown and therefore uncontrollable processes and initiatives can bud on the peripheries", giving "antisocial intentions of certain strata among the urban young" as well as "the growing sect-movements" that he relates primarily to rural areas, as examples (VARGA, D. 1982, p. 11). In reality, the spread of various free churches - a fairer description than sects that was indeed characteristic for Hungary in the 1980s (and 1990s) was more typical of ur- 
ban environments. Yet VARGA (ibid) recognises that "value can be created at the periphery, too; such artistic treasure that competes with the already familiar and recognised merits" (cf. LeE, L.O. 1991). Indeed, at times elements of folk culture - typically originating in rural places - such as handcraft, folk music and dance - have been important identity-markers of many societies, and even been more widely associated with the authentic national to gain political (KovácH, I. 2012, p. 32) but also commercial value.

An even more provoking and arguably also arrogant idea is raised in another volume by two young sociographers (Mátyus, A. and TAusz, K. 1984), namely that the servants - while "liberated" in 1945 - have got accustomed to dependence and for many of them self-dependence is often more dangerous than defencelessness. Nevertheless, the book series Gyorsuló idó that VARGA's and the latter work were included in set out to deal with contemporary social problems.

The years around the regime change in 1989 were a time for (a probably too incautious) optimism regarding the whole of Hungary's development, which might explain why issues of peripheralised areas stepped into the background. One remarkable and highly-prized exception is the novel Sátántangó (Krasznahorkai, L. 1985), adapted into a seven-hour long film in 1994 and published in English in 2012. The story - spread over a couple of days of endless rain - focuses on the dozen remaining inhabitants of an unnamed isolated hamlet, although the movie version is known to have been shot in Békés County (Stöckert, G. and Valuska, L. 2011).

It portrays "failures stuck in the middle of nowhere... Their world is rough and ready, lost somewhere between the comic and tragic, in one small insignificant corner of the cosmos. Theirs is the dance of death", as can be read on the website of the publisher of the English translation (New Directions 2015). The reviews published there describe the story as "an hours-long slog through mud and meaninglessness and superstition", KrASZNAHORKAI as "a poet of dilapidation", his work as "a bruising study of expectation and failure". In sum, a highly-prized work based on strongly negative images of Békés County, although implicitly.

The most influential contemporary writer from and on the southern Great Plain is most likely Krisztián Grecsó. His first book, recently published for the third time (Grecsó, K. 2013), is portrayed by a major distributor as "bringing fresh news from depths we rarely receive genuine reports from" (Libri 2015). The author himself is described as a native turned into an ethnographer, and "the question is left to the reader whether this makes him a traitor" (ibid). In Grecsó's latest book (2014), the Land of Storms carries with itself the notions of soil-boundedness, immutability, and forgottenness: "in the Land of Storms no miracles are taking place. There, waiting for miracles is a miracle in itself; the mirage that one day for someone it will be better - that there is such a thing as better at all" (Grecsó, K. 2014, p. 179). Accordingly, the book's main character begins asking himself whether his misfortunes are a result of his own decisions, or rather of his "land-ofstorminess" and thus, "peripheral" existence. The latter interpretation is supported by the book's title "I'm following you", reflecting a desire to leave, dependence and subordination - i.e. features widely associated with peripherality ( $c f$. LANG, T. 2012). Despite all the negative images surrounding it, and despite having moved to Budapest himself, the Land of Storms is also a place loved by Grecsó together with all its peripheral features.

Finally, an already-mentioned movie was presented at last year's Berlin Film Festival by the title "Land of Storms" (Császi, Á. 2014), thus, largely set in Békés County. The film was described as "a potently atmospheric drama of three young gay men wrestling with their sexuality in an unaccommodating environment" (RoONEY, D. 2014). One of the local characters "loosens up as barriers are broken down, but the pressure of his religious beliefs, his needy mother, a sometime girlfriend and the homophobic local youths fuels his conflict" (ibid). Whereas 
Békés County may not be known for its particular openness towards certain groups such as gays, characterising the region by piety and homophobia is rather misleading as neither religiosity (DövéNYI, Z. and NÉMETH, Á. 2014) nor support for the far right - however unsatisfying measures of homophobia - are typical features of the area.

\section{Popular scientific notions of peripherality and centrality}

Images and notions of peripherality and centrality are also (re)produced in popular scientific literature, including by geographers themselves. A good number of examples of this can be found in A Földgömb, the popular scientific journal of the Hungarian Geographical Society. While Hungarian borderlands and other areas conceived as peripheral are frequently covered, there is a number of interesting patterns regarding the ways these are described.

The vast majority of the articles are written from the centre's perspective, often using dichotomies like us/them or here/there, targeting audiences in "centres" like Budapest and other larger cities. A report on the Dráva Plain (PÁlfaI, L. 2002) - a micro-region along Hungary's southern borders - that bears the subheading "Faces of a forgotten landscape" starts off with the following: "the attributive in the subheading may perhaps appear as exaggerated, but if we start asking around in our acquaintanceship we will be astonished to learn how little people know about this land..." (ibid, p. 32).

In contrast, an account of the Bereg Region (PRISTYÁK, E. 2005) in north-eastern Hungary constantly talks of our values of the region. A quick search reveals that the author works at the local university college; thus, her local embeddedness might partly explain why she gives an impression of making attempts at advertising the region to tourists, by for instance starting the article by that "the Bereg is not only nice in July and August" and by using subheadings like "The magic of the Upper Tisza region" (ibid, p. 39). In some cases, the centre's perspective is particularly explicit. An article on the Csángós (KoKAs, A. 2013a) consistently contrasts their life to "yours" i.e. that of the imagined or targeted reader of A Földgömb. "You are always correlating! Your urban life to their rural existence... They live in the countryside in Romania. A bit off the map - in every respect." (ibid, p. 35) Finally, a foreword in a theme issue on Central Asia starts off by saying that it has never been easy for outsiders to get by in the region's hidden parts (NAGY, B. 2013, p. 1).

Certain places are also peripheralised by being depicted as forgotten or remote. Similarly to PÁlfaI's already-mentioned essay (2002), a contribution on the Tiszazug (Mezô, S. 2004) is subtitled as "A forgotten landscape in the heart of the Hungarian Great Plain". The next report in the same issue is on Lavenham, "where time stopped" (Ретнô, A. 2004, p. 44) despite the fact that today this English town is a popular day-trip destination for people from across the country. Of course, the image that "time stopped" in a certain place can also make it appear attractive, at least temporarily. Yet, probably few of us are drawn to places that are forgotten, at least in the longer run.

Rural and sparsely populated areas are often exotified and/or romanticised. A portrayal of Hortobágy (TAмÁsKA, M. 2004a) - a landscape of the Hungarian Great Plain often deemed as iconic in (national) historiography - describes it as "a romantic water world, with its timber-wolves, million fishes, shepherds, fishermen, hunters, wranglers, and crabbers, exiled into the works of ethnographers". Another essay commemorates the $200^{\text {th }}$ birthday of Sándor Rózsa, Hungary's most (in)famous scamp whose terrain was the Southern Great Plain (KoкAs, A. 2013b). The flourishing of rascally lifestyle in the region in the nineteenth century is explained by its then largely wild and impoverished character, where authorities had difficulties to maintain control and order (ibid, p. 27-29). At the same time, some regions - often already popular tourist destinations - are ascribed positively sounding slogans, thereby further contributing to their popularity. 
A contribution to a special issue on the Adriatic coastline is entitled "Portray of a «happy land»" (NemerkéNYI, A. 2004) - an earlier label by Le Corbusier (DE CAstro GonçALVES, J.F. 2013, p. 199). The already mentioned town of Gyula is sometimes referred to as the "pearl of the East". Unlike with many ascriptions of peripheries, in these cases the labels used are put within quotation marks. Nevertheless, one recent report (VJM.HU 2014) presents Békéscsaba in a positive light, claiming that the annual sausage-festival is now so popular that it makes the city the country's capital for four days, thanks to the locals' hospitability and so on (Photo 2). Interestingly, the label Land of Storms receives a different connotation here, understood as "the country's buttery" (ibid).

The contrast between the ways centrality and peripherality are portrayed is particularly apparent in two successive issues of Világjáró, a quality travel magazine. The

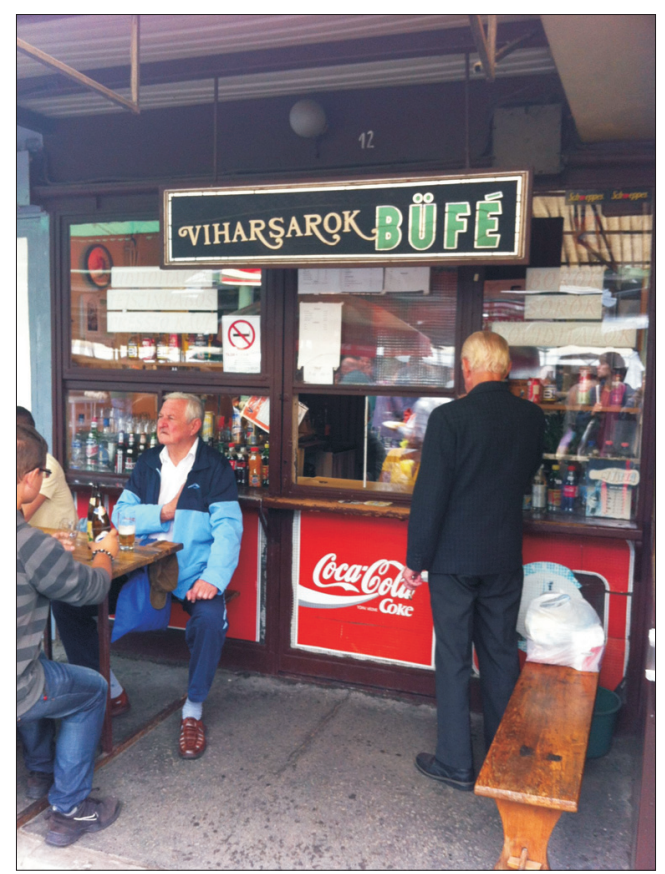

Photo 2. In the 2000s, the Land of Storms has typically been associated with an aging population and a lack of dynamism, but also with considerable potentials for food production and culinary tourism article on the Southern Great Plain bears the title "Treasures of meandering river valleys" (Szabó, V. and Siмкó, G. 2002). The second sentence says: “...this land was not only shaped by man's presence but also by his disappearance; as a result of depopulation under the Turks nature has reoccupied her realm" (ibid, p. 42). In contrast, the contribution on Budapest and the Central Danube Region is entitled "Where the country's heart beats" (Szabó, V. 2003). According to the introductory paragraph:

"If we look at Hungary's map, Budapest appears as a huge heart pumping blood through vessels - along the motorways and railroads - to the entire body of the country... It appears as if the heart of our weather-beaten country - and possibly of the entire world - has always beaten here" (ibid, p. 40).

The metaphor of a biological body representing a country - in this case Hungary - is interesting, though neither new nor unique. Already Ratzel, F. (1903) made the comparison between a state and a biological organism, with his idea later misinterpreted and abused by territorial revisionist decision-makers and scholars. The metaphor is of course not irredentist in itself; it does, however, represent and maintain an image of a country or nation as a clearly distinguishable unit with its own life and development. A biological body not least has a heart, brain, and limbs - comparably to a demarcated territory's centres and peripheries ( $c f$. BeEtz, S. 2008, p. 13). Another article from $A$ Földgömb on Prague (TAмáska, M. 2004b) is long describing the beauties of the city centre. According to the short final paragraph, then:

"Further away from Old town square ... a completely different world begins. The grey block-houses and factory-quarters surround as a modern city-wall all that we call Prague. It would be difficult to write about their features, probably only the after-ages will discover any beauty in them" (ibid, p. 17).

Finally, images of centrality can be maintained long after a place's central functions have diminished. As a report on Sztána, the "central place" (központos hely) of Kalotaszeg 
- a region of Transylvania - informs us, back in the days of steam locomotives all trains had to make a stop at this small and tranquil but picturesque village (TAMÁsKa, M. 2005, p. 43). When Károly Kós - a famous architect of the time - first spotted the area, he described his feelings as: "I' $\mathrm{m}$ just standing at the edge of the mountain, and I know, I feel every bit now that I'm standing right in the middle of Kalotaszeg, which has been giving me all the beauties of its wonders as a present..." (ibid). The area became a popular resort for Transylvanian intellectuals up until 1944 and even after fast-trains no longer stopped there it preserved the designation of a "central place", reproduced in TАмÁsKA's article and elsewhere. In Békés County, the geometrical centre of historical Hungary is since 1939 commemorated with a windmill at Szarvas (Szaвó, V. and Siмкó, G. 2002, p. 45).

\section{Conclusions}

The paper has testified tdorao the value of popular cultural and popular scientific sources in our search for the roots of longsurviving spatial images and discourses. The dominant image of Békés County is that of a peripheral area; it is striking that the term periphery (periféria) often features even in novels and sociographic works targeting a broad audience. The question then is what this peripherality and the epithet Land of Storms has meant for those who used them, and what kind of qualities have been ascribed to them. The analysis showed that the attributes assigned have altered significantly over time: while "land-of-storminess" mostly referred to toughness, severity, and a revolutionary spirit up until the 1950s, it has since the 1980s on the contrary been associated with passivity, tardiness, and tepidity. Indeed, Forsberg, G. (1996) pointed out that even the same place or landscape can be read in different ways, and Gruris, F. (2014) that spatial discourses can change in time. But what is interesting about these shifting images of the Land of Storms is that they have all the time been attributed to the region's peripherality. This is intriguing since features like a revolutionary spirit are not necessarily typical of peripherality. As an example, societal change including uprisings has at least in Hungary often been initiated in centres.

Most of the sources and the notions of peripherality produced are written from the centre's perspective. This is particularly true for popular scientific works that are largely written and read by audiences in the centres, who offer and are offered commercial and/or romanticised images of peripheral areas. In particular, portraying places as remote and/or forgotten (PÁLFAI, L. 2002; MEzô, S. 2004) most obviously reflects the writer's perspective, and possibly that of the target audience. It is illustrative that one of the few contributions written by a resident of a non-metroplitan region (PRISTYÁK, E. 2005) shows no signs of perceiving her area as remote - let alone forgotten. This confirms the observation by DE OliveIRA, S.M. (2002, p. 254) that while outsiders may perceive the local inhabitants as being at the periphery, they themselves do not.

Hence, categories like a distant location or poor connectedness reflect the viewer's angle: thus, Budapest is more distant and inaccessible for marginalised groups in Békés County than is the latter for car-owners in the capital - let alone the mental distances. Such attributes might of course be exaggerated by writers in order to make their cases more interesting, but that also contributes to the (re)production of images of peripheral areas as being essentially different from centres. As we saw even among older, well-established literary sources, authors such as ILLYÉs, GY (1937/1969) or at some point Mátyus, A. and TAusz, K. (1984) could make rather pejorative statements about peripheral areas. All the above supports the observation of PAAsI, A. $(1995$, p. 255) that "representations of the peripheries are typically constructed and defined in cores", thereby maintaining the established socio-spatial order.

What can all this imply for the development of a region like Békés County? As BEETz, S. (2008, p. 13) noted images are highly 
important for any place's development and investment potentials. Historical and recent associations with the label Land of Storms are not the most ideal for building a positive image of the region, nor for regional identity. In terms of socio-economic realities then, growing inequalities within and emigration from Békés County are only little compensated by a much smaller immigration and by modest cross-border flows (NAGY, G. et al. 2012). There is a real risk that the region remains a socio-economic black hole on Hungary's - and Europe's - map. Yet as other examples have shown, processes of peripheralisation are revisable (LANG, T. 2012, p. 1751; LUNDÉN, T. et al. 2009). Békés County's cross-border potential for instance near Gyula or Arad is not as exploited as in the borderlands around Satu Mare or Oradea in Romania (cf. ȚocA, C.-V. 2012) or Subotica in Serbia. The improving railway connections may bring further benefits. As images of the Land of Storms have been changing in the past, more positive associations with it (cf. VJM.HU 2014) may emerge in the future that should benefit the region - and thereby Hungary as a whole (cf. VARGA, D. 1982, p. 11).

Acknowledgements: The author thanks Judith MigGELBRINK and Gunnel Forsberg for their very valuable comments. The research and this article were completed during the author's participation in the project "ITN RegPol ${ }^{2}$ - Socio-economic and Political Responses to Regional Polarisation in Central and Eastern Europe", financed by the EU. The author is grateful to Thilo LANG, Alena Pfoser, Judit Timár, and Gábor Nagy for their helpful input to an earlier version of this paper.

\section{REFERENCES}

Avram, E. and First, A. 2006. Media, power and space: ways of constructing the periphery as the 'other'. Social and Cultural Geography 7. (1): 71-86.

Bakó, T., Cseres-Gergely, Z., Kálmán, J., Molnár, G. and Szabó, T. 2014. A munkaerópiac peremén lévók és a költségvetés (Those at the fringes of the labour market and the budget). Budapest, MTA KRTK Közgazdaságtudományi Intézet, 105 p.

Beetz, S. 2008. Peripherisierung als räumliche Organisation sozialer Ungleichheit. In Peripherisierung - eine neue Form sozialer Ungleichheit?
Eds. Barlösius, E. and Neu, C. Berlin, BerlinBrandenburgische Akademie der Wissenschaften, 7-16.

Browning, C.S. and Joenniemi, P. 2004. Contending Discourses of Marginality: The Case of Kaliningrad. Geopolitics 9. (3): 699-730.

BüRKNER, H. 2002. Border Milieux, Transboundary Communication and Local Conflict Dynamics in German-Polish Border Towns: The Case of Guben and Gubin. Die Erde 133. (1): 69-81.

Császi, Á. 2014. Land of Storms (Viharsarok). Budapest, Cirko Film.

De Castro Gonçalves, J.F. 2013. Motivation and consequence of travelling in the architecture of Le Corbusier: Voyage d'Orient and Latin-American travel. Cadernos Proarq (18): 195-214.

De Oliveira, S.M. 2002. Discourses of Identity at the Spanish/Portuguese Border: Self-Identification Strategies of Centre and Periphery. National Identities 4. (3): 245-256.

DövéNYI, Z. and NÉMETH, Á. 2014. A vallási diverzitás változása Magyarországon 2001 és 2011 között (Changes in religious diversity in Hungary between 2001 and 2011). Területi Statisztika 54. (6): 550-573.

ERIKSSON, M. 2008. (Re)producing a "Peripheral" Region - Northern Sweden in the News. Geografiska Annaler: Series B, Human Geography 90. (4): 369-388.

FÉJA, G. 1937/1980. Viharsarok (Land of Storms). $3^{\text {rd }}$ edition. Budapest, Szépirodalmi Könyvkiadó, 346 p. + images.

ForsberG, G. 1996. Rum med utsikter - modulationer på ett grundtema. Tidskrift för genusvetenskap (2): $15-23$.

Grecsó, K. 2013. Pletykaanyu (Gossipy mom). $3^{\text {rd }}$ edition. Budapest, Magvető, 192 p.

Grecsó, K. 2014. Megyek utánad (I'm following you). Budapest, Magvető, 304 p.

Grósz, M. ed. 1995. Csabai életrajzok (Békéscsaba profiles). Békéscsaba, Manuscript, 109 p.

Gyuris, F. 2014. The Political Discourse of Spatial Disparities: Geographical Inequalities Between Science and Propaganda. Berlin and Heidelberg, Springer, 381 p.

Hastings, A. and Dean, J. 2003. Challenging images: tackling stigma through estate regeneration. Policy and Politics 31. (2): 171-184.

Heiling Média Kft. 2015. A Földgömb magazin. Homepage of Heiling Média Publisher. Available: http://www.heiling-media.hu/a-foldgomb/mediaeszkozok/18-foldgomb-magazin. April 9, 2015.

ILlyÉs, Gy. 1937/1969. Puszták népe (People of the puszta). Budapest, Szépirodalmi Könyvkiadó, 243 p.

Kiss, A. 2014. Így néz ki hazánk jövedelemtérképe (This is what the income map of our country looks like). Metropol, September 24, 2014. http://www. metropol.hu/cikk/1233404-igy-nez-ki-hazank-jovedelemterkepe 
KoKAs, A. 2013a. Divat és valóság: Csángók itthonról és testközelből (Fashion and reality: Csangos at home and close-up). A Földgömb 31. (276): 34-47.

KoKAs, A. 2013b. Rózsa Sándor 200 (The $200^{\text {th }}$ anniversary of Sándor Rózsa). A Földgömb 31. (274): 24-34.

Kovách, I. 2012. A vidék az ezredfordulón: A jelenkori magyar vidéki társadalom szerkezeti és hatalmi változásai (The countryside at the turn of the millennium: Changing structures and power relations in contemporary Hungarian rural society). Budapest, MTA Társadalomtudományi Kutatóközpont Szociológiai Intézet - Argumentum Kiadó, 244 p.

Krasznahorkai, L. 1985. Sátántangó (Satantango). Budapest, Magvető Kiadó, 333 p.

LANG, T. 2012. Shrinkage, Metropolization and Peripheralization in East Germany. European Planning Studies 20. (10): 1747-1754.

LeE, L.O. 1991. On the margins of the Chinese discourse: Some personal thoughts on the cultural meaning of the periphery. Daedalus 120. (2): 207-226.

Lefebvre, H. 1974. La production de l'espace. L'Homme et la société 31. (1): 15-32.

Leibert, T. 2013. The Peripheralization of Rural Areas in Postsocialist Central Europe: A Case of Fragmenting Development? Lessons from Rural Hungary. In Peripheralization. Eds.: Fischer-TAHIR, A. and Naumann, M. Wiesbaden, Springer Fachmedien, 101-120.

Libri 2014. Pletykaanyu: Elbeszélések (Gossipy mom: Short stories). Homepage of Libri Publisher. Available: http://www.libri.hu/konyv/grecso_krisztian.pletykaanyu.html January 26. 2015.

Lócsei, H., Bublik, B. and Nyeste, A. 2013. Magyarország régióinak társadalmi-gazdasági profilja. (Socio-economic profile of Hungarian regions). Budapest, MKIK GVI Kutatási Füzetek, 220 p.

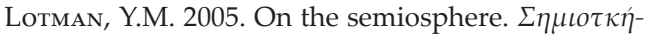
Sign Systems Studies 1. 205-229.

Lundén, T., Mellbourn, A., von Wedel, J. and BALOGH, P. 2009. Szczecin: A cross-border center of conflict and cooperation. In Conflict and cooperation in divided cities. Ed.: JańCZaK, J. Berlin, Logos Verlag, 109-121.

MATthiensen, U. 2002. Osterweiterung-BrandenburgPolen:Statement zum "Zukunftsforum Brandenburg 2025". IRS-Aktuell 37. 3-4.

Mátyus, A. and Tausz, K. 1984. Maga-ura parasztok és uradalmi cselédek (szociográfia) (Peasants and servants: a sociography). Budapest, Magvető Kiadó, 219 p.

Meyer, F. and Miggelbrink, J. 2013. The subject and the periphery: About discourses, loopings and ascriptions. In Peripheralization. Eds.: FIscherTahir, A. and Naumann, M. Wiesbaden, Springer Fachmedien, 207-223.

Mezó, S. 2004. Tiszazug: Egy elfeledett kistáj az Alföld szívében (Tiszazug: a forgotten microregion in the heart of the Great Hungarian Plain). A Földgömb 22. (4): 36-43.

Nagy, B. 2013. Nehezen elérhető (Difficult to access). A Földgömb 31. (3): 1.

Nagy, G., Nagy, E. and Timár, J. 2012. The Changing Meaning of Core-Periphery Relations in a NonMetropolitan "Urban Region" at the HungarianRomanian Border. disP - The Planning Review 48. (2): 93-105.

Nemerkényi, A. 2004. Egy "boldog vidék" portréja (Portray of a "happy land"). A Földgömb 22. (thematic issue), 14-20.

New Directions 2014. Satantango. Homepage of New Directions. Available: http://ndbooks.com/ book/satantango January 26, 2015.

Orosz, M. 2014. Hol élnek a legszegényebb magyarok 2014-ben? Itt a lista (Where do the poorest live in Hungary? Here is the list). Pénzcentrum, November 5, URL: http://www.penzcentrum.hu/vasarlas/hol_elnek_a_legszegenyebb_magyarok_2014_ben_itt_a_lista.1042520.html

PAAsI, A. 1995. The Social Construction of Peripherality: the Case of Finland and the Finnish-Russian Border Area. In Competitive European Peripheries. Eds.: Eskelinen, H. and Snickars, F. Berlin and Heidelberg, Springer Verlag, 235-258.

PÁLfaI, L. 2002. A Dráva-sík: Egy elfeledett táj arcai (The Dráva Plain: faces of a forgotten landscape). A Földgömb 20. (2): 32-43.

PÉnzes, J. 2013. The dimensions of peripheral areas and their restructuring in Central Europe. Hungarian Geographical Bulletin 62. (4): 373-386.

Ретно̋, A. 2004. Lavenham, ahol megállt az idő (Lavenham, where time stopped). A Földgömb 22. (4): 44-55.

PÉter, L. ed. 1994. Új Magyar Irodalmi Lexikon II. (New Hungarian Encyclopaedia of Literature II). Budapest, Akadémiai Kiadó, 799 p

Petras, J.F. 1976. Class and Politics in the Periphery and the Transition to Socialism. Review of Radical Political Economics 8. (2): 20-35.

Pristyák, E. 2005. A Beregben (In the Bereg). A Földgömb 23. (1): 38-49.

Ratzel, F. 1903. Politische Geographie: oder, die Geographie der Staaten, des Verkehres und des Krieges. München and Berlin, R. Oldenbourg, 838 p. incl. maps.

Rooney, D. 2014. Land of Storms (Viharsarok): Berlin Review. The Hollywood Reporter, August 2, URL: http:// www.hollywoodreporter.com/review/land-stormsviharsarok-berlin-review-678597

Shields, R. 1991. Places on the margin: Alternative geographies of modernity. London and New York, Routledge, $338 \mathrm{p}$.

Sмith, A. and Timár, J. 2010. Uneven transformations: Space, economy and society 20 years after the collapse of state socialism. European Urban and Regional Studies 17. (2): 115-125.

Soja, E.W. 1996. Thirdspace: Journeys to Los Angeles and other real-and-imagined places. Oxford, Blackwell, $334 \mathrm{p}$. 
Steinführer, A. and Kabisch, S. 2007. Binnenund Außenimage von Johanngeorgenstadt. In Schrumpfung an der Peripherie. Ein Modellvorhaben - und was Kommunen daraus lernen können. Eds.: Wirth, P. and Bose, M. München, Oekom Verlag, 107-123.

Stöckert, G. and VAluska, L. 2011. Csak nézni, ahogy telik a kurva élet (Just watching how the bloody life passes by). Index, April 13. URL: http://index. hu/kultur/2011/04/13/satantango/a_satantango_romos_kastelya/

Szaвó, V. 2003. Ahol az ország szíve dobog: Budapest és a Közép-Dunavidék (Where the country's heart beats: Budapest and the Central Danube region). Világjáró 3. (2): 40-44.

Szaвó, V. and Siмкó, G. 2002. Kanyargó folyóvölgyek kincsei: Dél-Alföld (Treasures of winding river valleys: Southern Great Plain) Világjáró 2. (11): 42-46.

TAMÁsKa, M. 2004a. "A pusztaságok pusztasága" (The wilderness of wildernesses). A Földgömb 22. (5): 28-39.

Tamáska, M. 2004b. Prága: Tamáska Máté írása az emberléptékü városról (Prague: Máté Tamáska on the human-scale city). A Földgömb 22. (3): 6-17.

TAмÁsKA, M. 2005. Sztána, Kalotaszeg „központos helye" (Sztána: the „central place” of Kalotaszeg) A Földgömb 23. (2): 42-50.
TAYlor, M. 1998. Combating the Social Exclusion of Housing Estates. Housing Studies 13. (6): 819-832.

Timár, J. and Kovács, Z. 2009. Hinterland Development. In International Encyclopaedia of Human Geography, Volume 5. Eds.: Kitchin, R. and Thrift, N. Oxford, Elsevier, 128-135.

TocA, C.-V. 2012. Romanian-Hungarian Cross-Border Cooperation at various territorial levels, with a particular study of the Debrecen-Oradea Eurometropolis (European Grouping of Territorial Cooperation-EGTC), Ph.D Dissertation, Doctoral School of Earth Sciences. Debrecen, University of Debrecen, $174 \mathrm{p}$.

VARGA, D. 1982. Az ország peremén: Körösnagyharsány szociográfiája (At the country's edge: Körösnagyharsány's sociography). Budapest, Magvető, 262 p.

VJM.HU 2014. Itt még a kerítés is kolbászból van? (Even the fence is made of sausage here?) October 24, VJM.HU, URL: http://www.vilagjaromagazin.hu/itthon/itt-meg-a-kerites-is-kolbaszbolvan/14989/

Wallerstein, I. 1974. The Rise and Future Demise of the World Capitalist System: Concepts for Comparative Analysis. Comparative Studies in Society and History 16. (4): 387-415.

WARF, B. and Arias, S. eds. 2009. The spatial turn: Interdisciplinary perspectives. London and New York, Routledge, $232 \mathrm{p}$. 


\title{
AQUINCUM Ancient Landscape - Ancient Town
}

\author{
Edited by \\ Katalin H. Kérdô and Ferenc Schweitzer \\ Geographical Institute Research Centre for Astronomy and Earth Sciences HAS
}

Budapest, 2014. 188 p.

Geomorphological-paleoenvironmental studies supporting archeological excavations and investigations are to be considered a new trend within the broader sphere of studies on environment and geomorphology. By publishing the latest achievements of researches of this kind carried out on the territory of Aquincum and in its wider surroundings this book may equally reckon on the interest of professional circles and inquiring audience.

Therefore the publication of such a volume of somewhat unusual character is welcome. The project could be completed as a result of the close cooperation of two important branches of studies, notably geography and archeology. They both have long lasting traditions in our country and on this occasion were represented by two prominent institutions, the Geographical Institute of the Hungarian Academy of Sciences, and the Aquincum Museum of the Budapest History Museum. Their contribution has made possible the publication of this book.

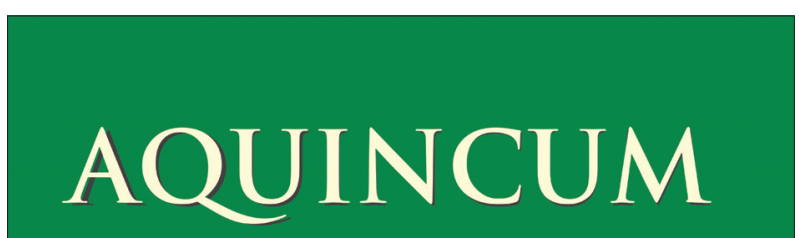

\section{Ancient landscape - ancient town}

Edited by:

Katalin H. Kérdő - Ferenc Schweitzer

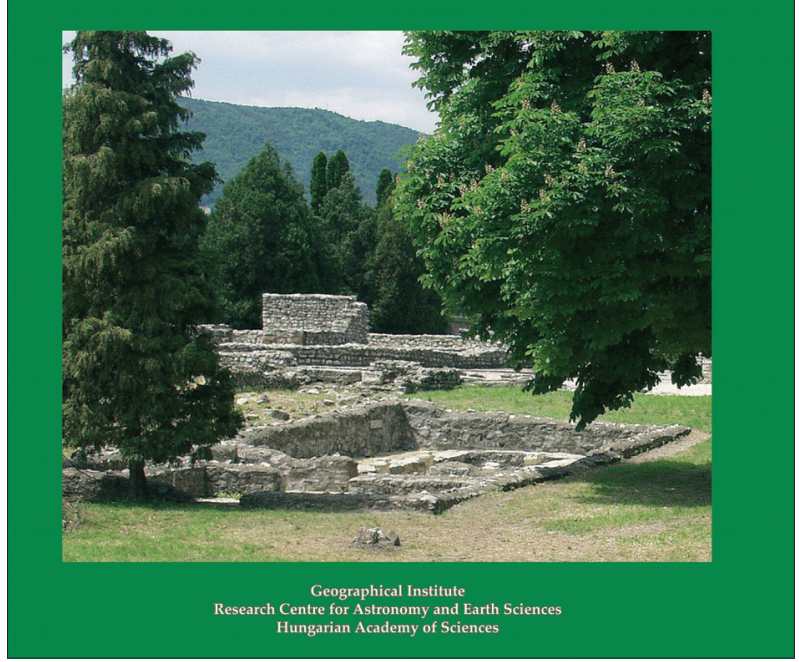

The studies were aimed to clear up the role of those natural factors which exerted a profound influence on the development of the settlement structure during the Roman Period. Romans had a special ability to realize advantages provided by geomorphological characteristics and they had made a good use of natural waters, flood-plain surface features and parent rocks for their creativity.

The volume is also deemed as a pioneering work with regard to the richly illustrated presentation of geological, geographical and other natural features exposed in several places in the course of archeological excavations. A short summary shows the most important objects of the Roman Period related to natural endowments and traces of activities of the time leading to environmental transformation.

Based on geomorphological evidence a new answer is proposed to a previously raised problem whether the Hajógyári Island existed as an islet already in the time of the Romans. Another intriguing issue tackled is the purpose of the system of trenches found in several places along the Danube River.

Price: EUR 20.00

Order: Geographical Institute of RCAES HAS.H-1112 Budapest, Budaörsi u. 44.

E-mail: magyar.arpad@csfk.mta.hu 